\title{
The English Pre-service Teachers' Politeness Strategies of Offering Context Across Genders
}

\author{
Anggi Aisyadatina, Susilo*, Yuni Utami Asih \\ Department of English Education, Faculty of Teacher Training and Education, Mulawarman University, Indonesia \\ angidatina34@gmail.com, olisusunmul@gmail.com, ami.setiobudi@gmail.com
}

\begin{abstract}
The purpose of this study is to find out the result of politeness strategy in offering context on male of sixth semester students, to find out the result of politeness strategy in offering context on female of sixth semester students, to find out significance difference result of politeness strategies in offering context between male and female of sixth semester students in Mulawarman University. The researcher invited 107 sixth semester students as the participants from population. They included 75 females and 32 males. The sample was given DCT Questionnaire Adapted from Al-Qahtani (2009) that included 15 acts about offering context. The DCT questionnaire was given to measure the politeness strategies that they used based on Brown and Levinson Theory. The study showed the mean score of the female was 4,2. It means that the average of politeness level from female students placed in middle level. Meanwhile, the mean score of the male was 3,4 . It means that the average of politeness level from male students placed in low level. The statistical analysis used t-test formula showed that the $t$ value was 4.969 with $\mathrm{df}=106$, and the level of significant at $5 \%$ was 1.98 . It can be concluded that $4,969>1.98$ or $t$-value $>t$-table. It means that alternative hypothesis (Ha) was accepted and null hypothesis (Ho) was rejected because there is a significance of politeness strategies between male and female of Mulawarman University.
\end{abstract}

Keywords-Politeness Strategies; Gender; EFL learners; University students; offering illocutionary act

\section{INTRODUCTION}

Understanding pragmatics for English students of teacher education is an urgent need since teaching foreign language should not only focus on formal aspect but also functional aspect of the language. Good language learners, thus, are those who are able to not only use language transactional but also interactional. Therefore, teaching it should also include teaching both aspects of language functions. Teaching a foreign language focusing on interactional function has a close relation to teaching character, i.e. becoming good communicators in every single real life business, which means the communicators should have politeness when speaking. Politeness is interesting and important topic because it can give an impact to attitude, manner and relationship between each people. [2] states that politeness strategies give a good opportunity for both speaker's and of hearer's interaction and communication. Meanwhile, [5], ensures that politeness is used in order to enter into social relationship, to acknowledge and show an awareness of the face, the public safe-image, the sense of self. In building the social relationship, Good English teachers who should be good speakers of English need not only how to teach, but also politeness strategies. This is so since teaching skills have always been evidently influenced by their L2 proficiencies.

The university governance system of each English teacher education institution in Indonesia apparently determines the extent of attainment of the students' teaching skills and English proficiency. For English teacher education in Indonesia, the direction of the university curriculum should be set by regulations issuing from the Ministry of Research, Technology and Higher Education. The higher education curricula used by all Indonesian universities to determine their learning outcomes should be fitted to the nine levels of qualifications stipulated that country's Qualification Framework; however, each university has the freedom to create the content of the curriculum in order that their graduates can be competitive in the labor force [31]. There have been more evidences supporting the fact that the teacher's role in teaching and students' achievements have a strong relationship [8, 11-13, $18,27,33]$.

Researches on politeness give ample of evidences that politeness employed by both female and male speakers is very important in the process of communication. For instance, politeness used in movie [15]; the importance of politeness used in offering context [3]; politeness in cross-gender [19, 22] and politeness in refusal context [7]. However, researches on politeness strategies used in the context of teaching and learning by pre-service teachers which focusing on differences of gender are not still often conducted. [26] investigating politeness strategies used in conversation in English textbook written by Indonesian writers, which reveals important findings on politeness strategies used in conversation in English textbooks. The present study aims at investigating how politeness is employed by the EFL students of teacher education. Specifically, this study has three questions as follows

1. What politeness strategies are used in offering context across gender by the EFL pre-service teachers?

2. Do male and female EFL pre-service teachers differ in their politeness strategies of offering context? 


\section{REVIEW OF RELATED LITERATURES}

\section{A. Concept of Politeness}

Politeness strategy is a branch of pragmatics and discourse study. Based on Brown and Levinson's theory, there are 4 strategies of politeness; bald on record, positive politeness, negative politeness and off-record. The concept discussed in the definition of politeness. [9] stated that politeness is the act to increase good behavior. It includes the way you give honorable to people and the way you say to people. According to [20], politeness can determine the social status of someone and can be intellectual reflection of the speaker. Furthermore, [32] said that politeness is pragmatic rules would have to be grounded in a notion of pragmatic competence. In the same case, [5] said that Politeness is a principled reason for deviation from the cooperative principle when communication is about to threaten face. Politeness will be the tool to integrate the communication. It can be the strategies to make the language soften and minimize negative face. The good speaker will be give consideration to the hearers' feeling. Because the way we talk reflects on the way we are.

In this study, the researchers use politeness strategies theory from [5]. They divide politeness strategy into four types: 1) bald on record, 2) positive politeness, 3) negative politeness, and 4) off record. The politeness strategies are the set of tools that include the problem in social distance (D), power (P) and rank of imposition (R). Social distance is the relationship between speaker and hearer in communication. If two people are very close, they have low degree of social distance and they usually do not use polite words to speak with each other and vice versa. Power refers to the power relationship in communication like position in society, age and social status. There are three kinds of power relationship. The first is equal powers between friends and colleague. The second is someone who has more power relationship, like boss, teacher or lecturer. The third is less power relationship, like brother, sister, students when you are teacher and employee when you are boss. And rank of imposition is the importance or degree of difficulty situation, the situation in emergency or not and how big the something that speaker wants to offer or not [5], Fig. 1.

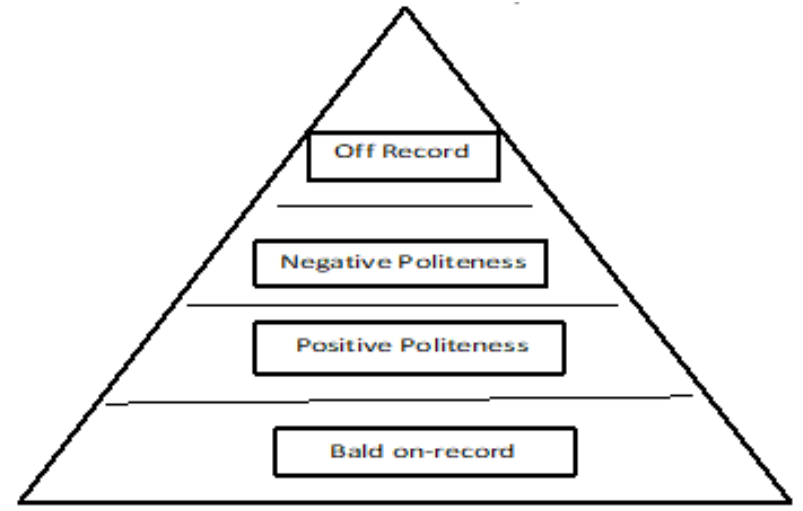

Fig. 1. Level of Politeness Strategy adapted on Brown and Levinson's Theory

In addition, politeness strategies are maintaining the hearers' face threatening act. The face threatening act is measured an appropriate behavior [5]. It consists of negative face and positive face. If the value of (FTA) high, the speaker will choose a strategy with high number. This chart will give possible strategies of politeness, Fig. 2.

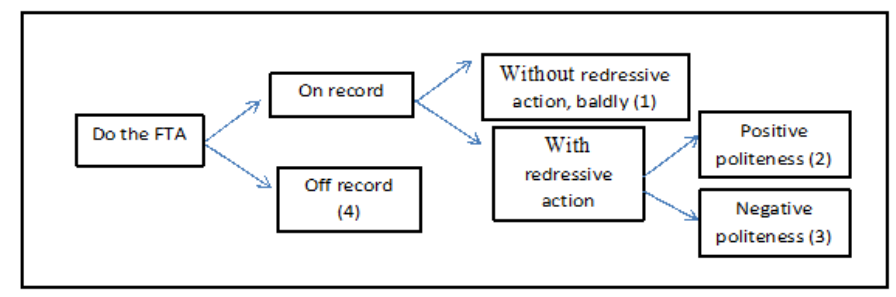

Fig. 2. Face threatening act $[5,16]$

Each stage of politeness strategies has some characteristics. The characteristic is the way to determine the situation that is suitable from those strategies. These characteristics can help the researchers to categorize the levels and the kinds. The characteristics of FTA shown is that which is explained by [16]. The first strategy is bald on record. Bald on record is the lowest level of politeness strategy. There are some cases that can be applied as bald on record, 1) including instances of nonminimization of the face threat and 2) avoiding ambiguity 3 ) suitable in emergency situation. Bald on record has special characteristic. Bald on record happens when someone say in direct ways. For the example when someone offers something "it seems hard, I will help you with your work" or "let's try this cake that I made".

The second strategy is positive politeness. Positive politeness placed above bald on record in the chart level. This strategy has a function to reduce the distance in communication. It is the way to make hearer feel good when they are hearing our conversation. It also makes the conversation become friendly rather that stiff. The characteristic of politeness is the way speaker talk to other is semi direct. For the example in offering something "you look so sad, can I do something for you? This strategy is like seek an agreement to hearer.

The third strategy is negative politeness. Negative politeness has second rank in the chart level. This strategy for self-protection, the speaker does not want to be label as a person who is too friendly after just being introduced. The characteristic is the meaning will be explaining with semi indirect. For the example offering.

Something “I am sorry before, I don't mind something. But could you please accepted my present", "excuse me sir, is there any trouble that bother you? Could I help you?", "I am sorry for asking you, is there something that I can help for you?" or "excuse me Sir, are you looking for your bag? If it is not bother you, I will help you to find it Sir. This strategy uses prolog before speakers tell the point.

The last is off record strategy. Off record has highest level in char level of politeness strategies. The characteristic off record is something explains in indirect way. The communication in this strategy is ambiguous. The hearers have to determine the meaning by themselves. The Speakers usually use the words that have connection with the meaning. This is also the way to avoid offended feeling or negative face. For 
the example offering something "my dress really suit on you" or "your bag looks heavy".

\section{B. Concept of Offering Context}

In politeness strategies there are some contexts that can be measured in politeness. [21] stated that contexts in politeness strategy include greeting, apologizing, congratulating, offering and inviting. But in this case, the researchers use offering context because [17] stated that offering context is reflected of sincerity from speaker to hearer. It makes social interaction suitable to all social acts and can be natural ways to choose politeness strategies. According to [1], offering is a situation when people try to cooperate with each other and help each other. Offering usually has a link with agreement because when speakers want to offer something with hearers, they usually seek an agreement. If the hearers agree with that, the speaker will do something to make offering happen and vice versa. Based on the explanation above, the researcher concluded that offering is a condition when someone or people try to do or to give helps and something to others. Offering can be categorized as a speech act which reflected with the sincerity.

\section{Concept of Gender and Sex Differences between Gender and Sex}

In sociological approach, there are differences definition and characteristics between sex and gender. It looks like the same but actually it is different. According to [25] sex is something that linked in difference biological structures like chromosomes, hormonal profiles, internal and external organ. Meanwhile, gender represents to the characteristics of social and cultural roles. [10] stated that sex has been used in terms of biological context. In the other hand, gender has been used in social or cultural context. In the same explanation, [24] stated that sex is representing to the anatomical and biological, such as the body, chromosome and hormone. In addition, gender is representing social and culture role, such as family interaction, media, peers, and education.

From the definition above the researcher concluded that the differences between gender and sex are placed in their contexts. When sex is identically with anatomical and biological context, gender is identically with social and culture role. Both of them have their own characteristics in specific aspect.

[30] argued that male will generally respond by defining themselves as masculine and has worker role in the society. [6] stated that male can be identification with masculinity, necessary to attain the correct gender role, happens through rejecting what stands for femininity. The definition above can conclude that male is a kind of gender with the masculinity characteristic of their behavior or role in the society. According to [30] females will generally define themselves as feminine. The female investigates the role of themselves as a domestic role. Female reflected themselves as a soft role. In $18^{\text {th }}$ century, female has a position under the man. And in that era, female has no freedom to express their idea. Male and female have different point in some aspects, such as behavior, act, and mindset. In the Female characteristics usually identical with the soft feeling, grace act and behavior and soft mind because they usually use feeling rather than logical reason. In the other hand, male usually identical characteristics with masculinity behavior, strong character and use logical thinking rather than feeling.

All of the statement above is the way to described and explained about the characteristics male and female. It depends on their behavior, character, act and the way they think about something.

\section{Gender and Politeness}

In the discussion above, we know the differences characteristics between male and female. In this discussion, the researchers will explain the differences politeness between male and female or men and women. [6] stated that male and female have their biological characteristic to express the language. Male's language is dominant, direct, and formal. Meanwhile, female's language is feminine, inferior, powerless and indirect. In addition, [4] said that female use the language politeness to influence the connection. In the other hand, male use the language politeness to assert their independence. [23] argued that Female has a politeness language than male in the question tag.

\section{E. Review of Previous Studies}

There some previous study which have differences and similarities from each other. The first similarity and difference are there were for about five previous studies about politeness strategies which have same theory of politeness strategy based on Brown and Levinson theory. The first is [15] analyzed about Politeness Strategies used in Nanny McPhee Movie. The second is [3] has investigated Female Use of Politeness Strategies in Speech Act. The third is [19] have made a research about A Socio-linguistics Survey on Females Politeness Strategies in the Same Gender in the Cross-Gender Relationship. The fourth is [22] has a study about Adapting Brown and Levinson Theory to analyze about Casual Conversation. And the last is [7] about Refusal and Politeness Strategies in Relation to Social Status. The second similarity and difference are about the context. From the previous studies, there is no similarity in the context politeness strategy. But there were differences contexts in politeness strategy in previous studies. [4] has measured politeness strategies in offering context and [7] has measured politeness strategies in refusal context. Meanwhile, [15, 19] did not use any specifics context in their studies.

The third similarity and difference are about the types of politeness strategies. Actually, those previous studies did not use any specifics types that they wanted to measure. So, all types allowed to be found in those studies. But according to result, there is specific type that dominant in those studies. the similarity of the types in those studies are from [15] which found positive politeness $44 \%$ as the dominant result, [22] also found positive politeness in his study. Meanwhile [3] found negative politeness as dominant types and [22] also found negative politeness in his study. The difference is from $[6,19]$. [6] found indirect types $52 \%$ in her study and [19] didn't search the types but the reason of speech act in his study like try to comfort, explain the reason, and offer compensation. 
The fourth similarity and difference are about the instrument that they used. [3, 6, 19] used Discourse Completion Test Questionnaire as their instruments. Meanwhile, $[6,22]$ used transcript as their instruments.

The previous studies have similarities and differences with this study. The first similarity is about the theory. All of the previous study used Brown and Levinson theory. This study also used Brown and Levinson theory as the basic theory to determine politeness strategies from sixth semester students in Mulawarman University. And there is no difference in theory the second similarity is the instrument. The researcher used Discourse completion test as the instrument of this study. DCT questionnaire also used by $[3,6,19]$ for their instruments of their studies. In the other hand, $[15,22]$ used transcript data as their instrument whish different from instrument in this study. Moreover, the researcher adapted DCT questionnaire from [3] as the instrument of this study. The last similarity and difference are about the context. This study has similarity about the context with [3]. Both of these study used offering context. It was difference from [6] which used refusal context for her study.

From all the explanation above, it concluded that this study has differences and sameness from previous [3] as the instrument for this study.

\section{METHOD}

The design of the study was ex post facto, i.e. causal comparative research which has a function to find relationship between two groups after action, i.e. in this case, the researcher compared the politeness strategies used by male and female students of pre-service teacher education in Mulawarman University.

The population of sixth semester students in Mulawarman University is 128 students which contain 35 males and 93 females. This study used Random Sampling of sixth semester students of English Department, Mulawarman University. From the calculation with the formula above, the researcher has been measured the sample of population. The sample of male is 32 and the sample of female is 75. The type of Random sampling is Lottery Sampling. [29] stated that Lottery random sampling while the researcher divided the sampling into randomly and without looking. The researcher divided sample based on their gander and write two last of their students' number in some pieces of papers.

In collecting the data in this study, the researcher used Discourse Completion Test (DCT) questionnaire adapted from [3] is used to measure their Politeness Strategies. The DCT questionnaire contains 15 items of open question types in offering context. This instrument is validated by consulting it to the experts, i.e. expert judgment. Besides, the reliability of the instrument is ranging between 0.7578 and 0.8825 , which means it has been statistically acceptable. Furthermore, the alpha was total $=0.9295$ which is significantly high. This study uses independent t-test to measure the significant difference between politeness strategies in offering context used by female and male EFL pre-service teachers.

\section{RESULTS AND DISCUSSION}

\section{A. Politeness Strategies in Offering Context done by the Female Students}

On the basis of the results of DCT questionnaire, it is shown in Fig. 3 that there are 75 students achieving different scores.

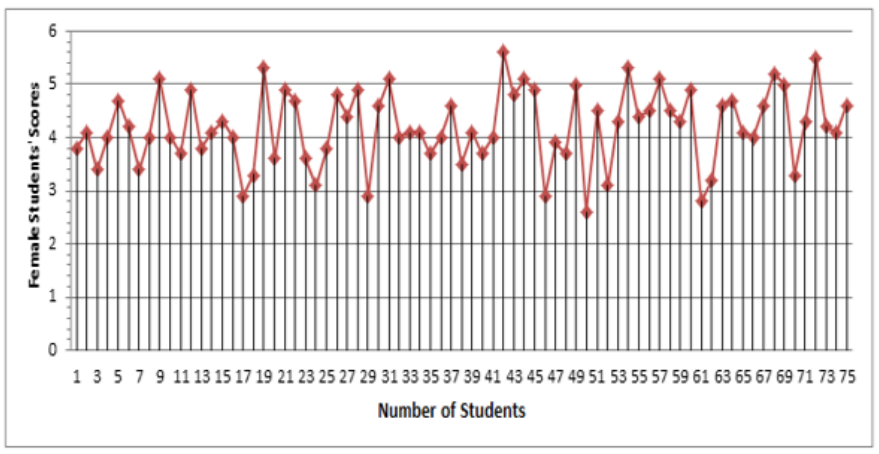

Fig. 3. Scores of the questionnaire from female students

Fig. 3 indicates that from 75 female students, the higher score from female students was 5.6 and the lowest score was 2.6. There were 52 students who achieve middle level with number of score 4-5 and 23 students who achieve low level with number of score $2-3$. The total number of scores from female is 314.8 .

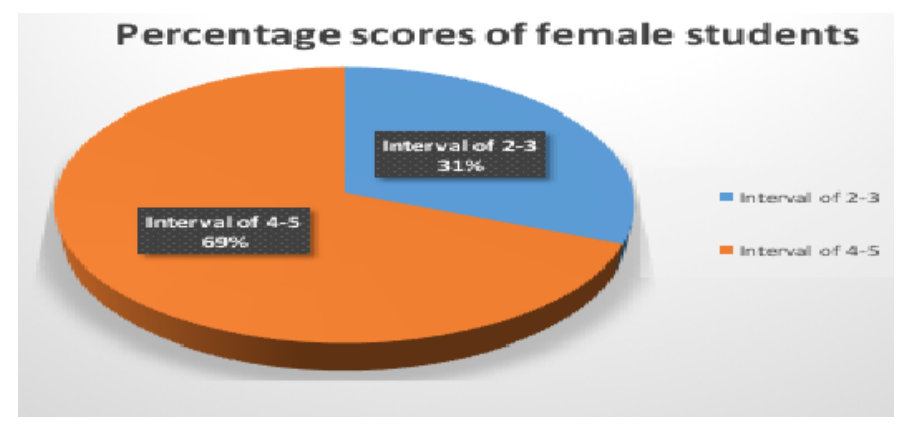

Fig. 4. percentage of scores from female students

As it is seen in Fig. 4, the result reveals that the female students who get the interval score of $2-3$ are $31 \%$; while those who get the interval scores $4-5$ are $69 \%$. Furthermore, it is found that female students use negative politeness and positive politeness types as the politeness strategies to answer the questions. 
Percentage scores of the types of politeness strategies

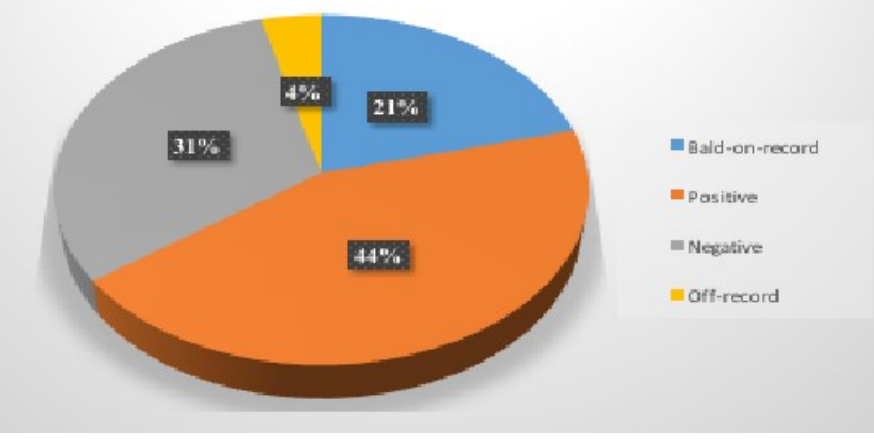

Fig. 5. Percentage of the types of politeness strategies from female students

Fig. 5 shows that positive politeness is mostly used by the female students (44\%), i.e. there are 499 students who take this politeness. This strategy wants to make the speaker become friendlier in communication. It can reduce awkward and stiff situation. This is an example of positive politeness strategy used in questionnaire number 3, 8, 11, 12 and 15.

From the figures above, the average from the questionnaire test result is 4.23 , which means that the level of politeness strategies that they used is middle because they usually use positive, negative and off record politeness strategies rather than bald on record politeness strategies. The conclusion which can be drawn is that the female students usually use indirect and semi indirect words when they offer something, that is why the average of result placed in the middle level. For the standard deviation is 0,70 which means that the scores are not really different from each other because the result of standard deviation is not high. The lower the result of standard deviation is, the more nearby the scores from each other are. The higher the result of standard deviation is, the more far the scores from each other are.

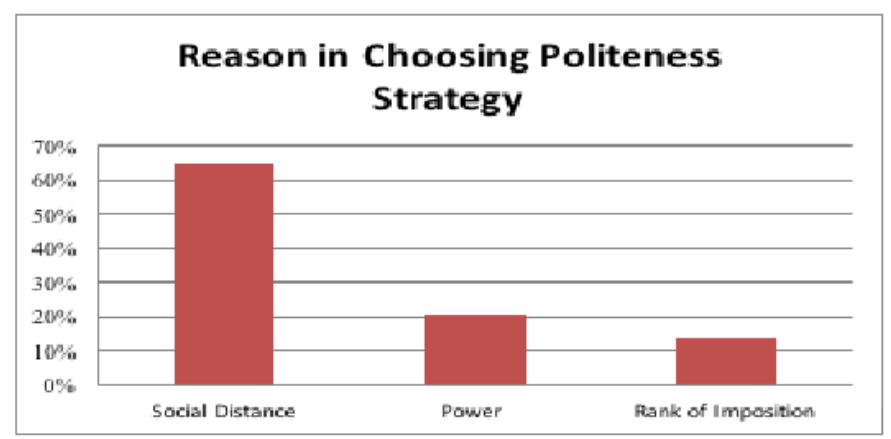

Fig. 6. Reasons for choosing politeness strategies for female students

Fig. 6 indicated the percentage of the reason that they chose to determine their politeness strategies to answer the questions. The dominant reason was social distance $65 \%$. This is an example that found in the questionnaire number 15 .

\section{B. Politeness Strategies in Offering Context done by the Male Students}

Fig. 7 represents male students' scores of DCT questionnaire about offering context. It indicates that from 32 male students the higher score from male students was 5.1 and the lowest score was 2.2. There were 10 students who achieved middle level with number of score 4-5 and 22 students who achieved low level with number of score $2-3$.

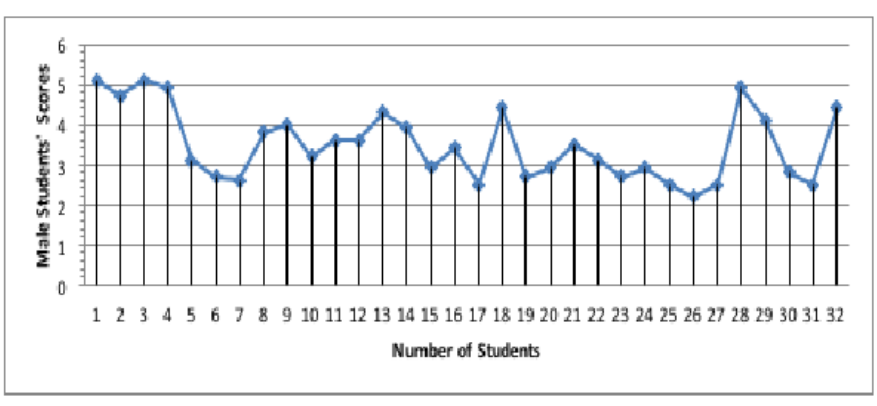

Fig. 7. Scores of DCT questionnaire from male students

Meanwhile, Fig. 8 indicates the percentage of scores in male students. This figure shows that the male students who got score $2-3$ were $69 \%$ and the male students who got scores 4-5 were $31 \%$. It means that male students usually used bald on record types and positive politeness types as the politeness strategies to answer the questions. According to the scoring system, bald on record types just gives low score in accumulation.

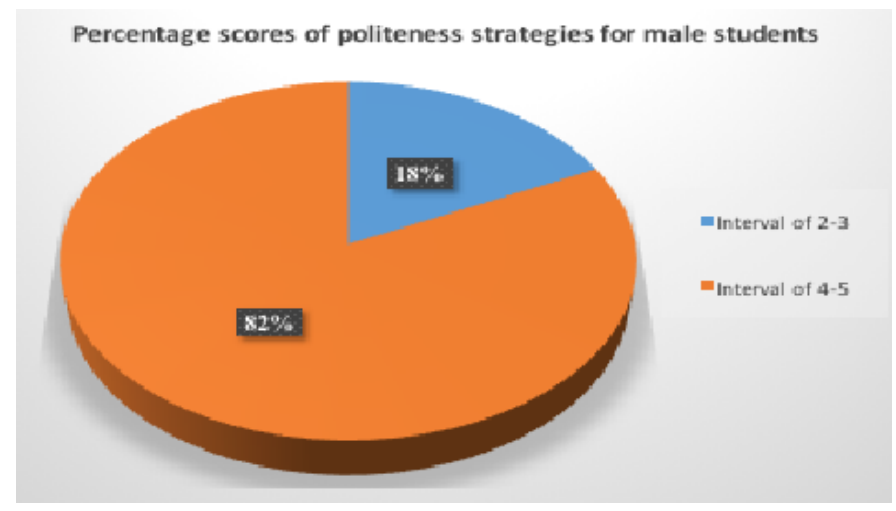

Fig. 8. Percentage scores of politeness strategies from male students

In term of types of politeness strategy, as shown by Fig. 9, positive politeness is placed in the first position with percentage of $41 \%$ and frequency occurrence of 196 , the same as the female percentage showing the dominance of positive politeness in the questionnaire. Positive politeness has a function to make atmosphere friendly and uses semi direct words.

Fig. 9, the average from the questionnaire test result is 3.48, which means the level of politeness strategies that they used is low because they usually use bald on record politeness strategies rather than positive, negative and off-record politeness strategies. The conclusion is that the male students usually use direct and semi direct words when they are offering something, that is why the average of result is placed in the low level. The standard deviation is 0,88 which means that the scores are not really different from each other because the result of standard deviation is not high. The lower the result of standard deviation is, the more nearby the scores from each 
other are. The higher the result of standard deviation is, the more far the scores from each other are.

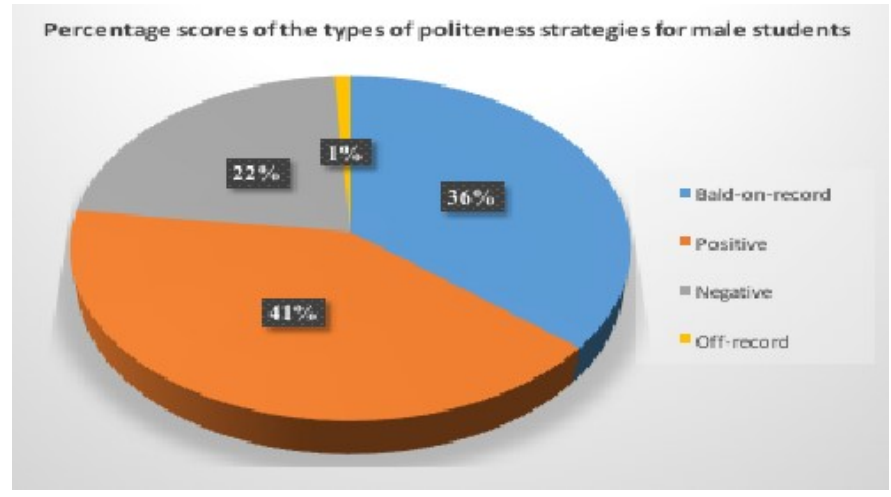

Fig. 9. Percentage of the types of politeness strategies for male students

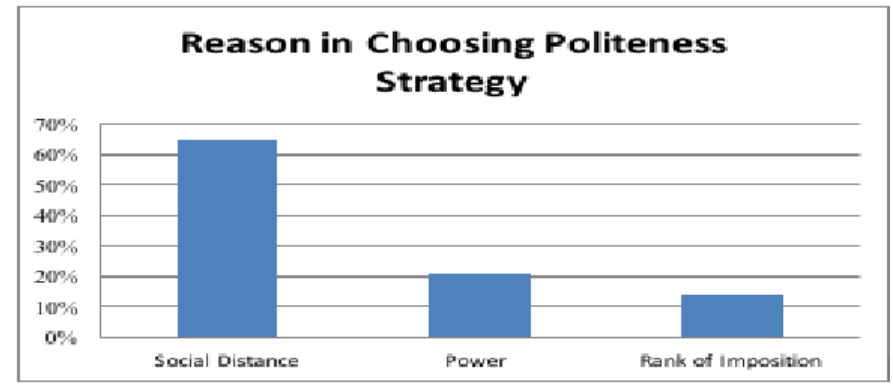

Fig. 10. Reasons in choosing politeness from male students

In addition, figure 8 indicates the percentage of the reason that they chose to determine their politeness strategies to answer the questions. The dominant reason was social distance $65 \%$. There are two kinds of social distance, far and close from each other.

\section{The Result of t-test comparing means of the Politeness Strategies done by Female and Male Students}

On the basis of the normality test as shown in Table I, it could be interpreted that the both of the data have normal distribution. The result shows that the data from female data has the value of sig. of lo which is bigger than t-table of 0,05 $(0,966>0,102)$. It is also proved with male data has the value of sig. of lo which is bigger than t-table of $0,05(0,943>$ $0,157)$. Therefore, the distribution is normal.

TABLE I. THE STATISTICAL RESULT OF THE NORMALITY TEST

\begin{tabular}{|l|l|l|l|l|}
\hline Group & N & Mean & SD & $\begin{array}{l}\text { Lilliefors } \\
\text { (sig. of Lo }>\text { L table 0.05) }\end{array}$ \\
\hline Female & 75 & 4.2 & .70 & $0.966>0.102$ \\
\hline Male & 32 & 3.4 & .88 & $0.943>0.157$ \\
\hline
\end{tabular}

Furthermore, as shown in Table II, the result of t-test is 4,97. The degree of the freedom of the sample was 106. The level significance and the t-table value was 1,98. Because the value $=(4,97>1,98)$, it showed that the null hypothesis (Ho) was rejected and alternative hypothesis $(\mathrm{Ha})$ was accepted.
TABLE II. THE STATISTICAL RESULT OF THE T-TEST

\begin{tabular}{|c|c|c|c|c|c|c|}
\hline Group & $\mathrm{N}$ & Mean & SD & $\begin{array}{l}\text { Sig. } \\
\text { Lo }\end{array}$ & t-test & df \\
\hline & & & & & $\begin{array}{l}\text { (t-computation }>\text { t-table } \\
0.05)\end{array}$ & \\
\hline Female & 75 & 4.2 & .70 & .966 & \multirow[t]{3}{*}{$4.97>1.98$} & \multirow[t]{3}{*}{106} \\
\hline Male & 32 & 3.4 & .88 & .943 & & \\
\hline Total & 107 & & & & & \\
\hline
\end{tabular}

\section{DISCUSSION}

Based on the result above, the researchers made some interpretations. The interpretation is made to make a clear explanation of politeness strategies between male and female of the pre-service teachers studied in Mulawarman University. The result from male students showed that the mean is 3,4 which is considered as a low level. There are 10 students or 31 $\%$ who gets scores of 4-5 (middle) because they often use positive, negative and off-record politeness strategies to answer the questions in the DCT Questionnaire and the other 22 students or $69 \%$ get the scores of under 4 (low) indicating that they often uses bald on record politeness strategies to answer the questions in the DCT Questionnaire. The standard deviation is 0,88 , which means the data are not really different from each other.

In the other hand, the result of female students shows that the mean is 4,2 , which is considered as a middle level. There are 52 students or $69 \%$ who get scores of $4-5$ (middle) because they often use positive, negative and off-record politeness strategies to answer the questions in the DCT Questionnaire and the other 23 students or $31 \%$ get scores of under 4 (low) meaning that they often use bald on record politeness strategies to answer the questions in the DCT Questionnaire. The standard deviation is 0,70 , which the data are not really different from each other.

Furthermore, the normality distribution test interprets that both of the data from male and female have normal distribution. The value from sig. of lo is greater than $\mathrm{L}$ table of 0,05 . The value from female is 0,966 ( $t$-calculation) which is greater than 0,105 (t-table) and the value from male is $0,943(\mathrm{t}-$ calculation) which greater than 0,157 (t-table). Therefore, it can be concluded that the data is parametric data because have normality distribution and used t-test as the tools to compare those data.

Based on the result of normality test, the researchers calculated the t-test; and the result shows that $\mathrm{t}$-calculation is 4,97 , which is greater than t-table $(1,98)$ of 0.05 . It means that alternative hypothesis (Ha) was accepted and null hypothesis (Ho) was rejected. It is further said that there is a significant difference result of politeness strategies done by the male and female students of Mulawarman University. From the standard deviation, it shows that female students have higher level of politeness strategy because the results were higher than male students. It implies female pre-service teachers studied in Mulawarman University are more polite to choose the words in offering context rather than the male ones.

The result of the current study is confirming the previous studies in similar contexts $[3,6,21]$. All these studies found 
that types of politeness strategies are used variously in various contexts. This confirms the current studies that politeness strategies are also used variously by the pre-service teachers in Mulwarman University.

\section{CONCLUSION}

The sum of result from politeness strategies from female pre-service teachers studied in Mulawarman University was 314,8 with the mean was 4,2 that indicated as a middle level. The sum of result from politeness strategies from male ones is 111,5 with the mean was 3,4 that indicated as a low level. Meanwhile, there is a significance difference of politeness strategies between male and female pre-service teachers. This implies that female pre-service teachers have higher level of politeness strategy than the male ones.

\section{REFERENCES}

[1] Ad-Darraji, H.H.A., Foo. T.C.V., Ismail, S.A.M.M., Abdulah, S. (2012). Offering as a Comissive and Directive Speech Acts: Consequence for Cross-Cultural Communication. Journal Scientific and research Publication, 2 (3): 1-6

[2] Adel, S. M. R et al. (2016). A Qualitative Study of Politeness Strategy Used by Iranian EFL Learners in Class Blog. Iranian Journal of Language Teaching Research, 4 (1): 47- 62

[3] Al-Qahtani, H.A. (2009) Female Use of Politeness Strategies in Speech Act Offering: A Contrastive Study between Spoken Saudi Arabic and British English. Unpublished thesis: Riyadh: King Saud University

[4] Batanieh, R., \& Batanieh, F. (2008). A Cross-Cultural Comparison of Apologies by Native Speaker of American English and Jordanian Arabic. Journal of Pragmatics, 40: 792-821

[5] Brown, P., \& Levinson, S.C. (1987). Some Universal of Language Use. Cambridge: Cambridge University Press.

[6] Cameron, D. (2005). Language, Gender, and Sexuality : Current Issue and New Direction. Applied Linguistics, 26: 482-502.

[7] Chojimah, N. (2015). Refusal and Politeness Strategies in Relation to Social Status: A Case of Face Threatening Act among Indonesian University Students. Theory Practice Language Study, 5 (5): 906-908

[8] Conti, G. \& Welborn, R. (1996). Teaching learning styles and the adult learner. Lifelong Learning, 9 (8): 20-24

[9] Culpeper, J. (2011). Politeness and Impoliteness. Sociopragmatics, 5: 141

[10] Diamond, M. (2002). Human Social Development Biological Foundation for Social Development. Clinical Child Psychology and Psychiatry. 1: 22-61

[11] Ferguson, R. (1998). Teachers' perceptions and the black-white test score gap. In C. Jencks and M. Phillips (Eds.). The Black-White Test Score Gap (pp. 273-317). Washington, DC: Brookings Institution Press.

[12] Ferguson, R. F. (1991). Paying for public education: New evidence on how and why money matters. Harvard Journal of Legislation, 28: 465498.
[13] Goldhaber, D. (2002). The mystery of good teaching: Surveying the evidence on student achievement and teachers' characteristics. Education Next, 2(1), 50-55.

[14] Goodrick, D. (2014). Comparative Case studies. Unpublished Unicef document. Florence, Italy: Unicef Office of Research.

[15] Hasmi, M. (2013). A Pragmatics Analysis of Politeness Strategies Reflected in Nanny McPhee Movie. Unpublished thesis. Yogjakarta: Yogyakarta State University

[16] Holtgraves. (2008). Politeness : Prown and Levinson. Language as Social Action, 2: 37-64

[17] Hua, Z., Li, W., \& Yuan, Q. (2000) The Sequential Organization of Gift Offering and Acceptance in Chinese. Journal of Pragmatics, 32 (1): 81103

[18] Jarvis, P. (2004). Adult education and lifelong learning: Theory and practice. London: Routledge Falmer.

[19] Kaikhaie, Y., \& Mozaffari, Z. (2012) A Socio-linguistics Survey on Females Politeness Strategies in the Same Gender and in the CrossGender Relationship. Iranian Journal of Applied Linguistics Studies, 5 (2): $1-32$

[20] Kassberg, H. (2012). Politeness Strategies-A Theoretical Framework. Sociolinguistics Observation of politeness. 1: 1-29

[21] Kedves, A. (2013). Face Threatening Acts and Politeness Strategies in Summer School Application Calls. Jezikoslovlje. 3: 431-444

[22] Kitamura, N. (2000). Adapting Brown and Levinson's Theory to the Analysis of Casual Conversation. Proceedings of ALS2k Conference of the Australian Linguistics Society.

[23] Lakoff, R. (1975) Language and Women's Place. NY : Harper and Row

[24] Newman, T. (2016). Sex and Gender: What is Difference?. Retrieved March $\quad 3^{\text {rd }} \quad 2017, \quad$ from http://www.medicalnewsstudy.com/articles/232363.php

[25] Nobelius, A. (2004). What is the Differences between Sex and Gender? Retrieved March 2 $2^{\text {nd }}$, 2017, from http://www.med.monash.edu.au /gendermed/sexandgender.html

[26] Rahmawati, Y. (2013). A Study on Politeness Strategies Used in Conversation in English Textbooks Written by Indonesian Writers. Unpublished thesis. Samarinda: Mulawarman University

[27] Sanders, W. L. (1998). Value added assessment. School Administrator, 11 (55): 24-27.

[28] Sanders, W. L. (2000). Value-added assessment from student achievement data. Cary, NC: Create National Evaluation Institute.

[29] Singh, A.S., \& Masuku, M.B. (2014). Sampling technique \& determination of sample size in applied statistics research: an overview. International Journal of Economics, commerce and management. 2 (11): $1-22$

[30] Stets, J.E., \& Burke, P.J. (2000). Feminity/Masculinity. Encyclopedia of Sociology.

[31] Susilo, S. 2015. Curriculum of EFL teacher education and X country (pseudonyms) qualification framework: a blip of the future direction. Dinamika Ilmu, 15 (1): 11 -24.

[32] Watts, R.J. (2003). Politeness. Cambridge: Cambridge University Press

[33] Wright, S. P., Hom, S., P, \& Sanders, W., L. (1997). Teacher and classroom context effects on student achievement: Implications for teacher evaluation. Journal of Personal Evaluation in Education, 11, 5767. 